\title{
Death of Mrs. M. Gautier-van Berchem
}

Mrs. Marguerite Gautier-van Berchem died on 23 January 1984, to the deep sorrow of all those who had the privilege of knowing her.

The daughter of the well-known scientist Max van Berchem, Marguerite Gautier continued in her father's footsteps and became a scholar in the field of archeology. She was the author of a number of highly esteemed publications.

When the First World War broke out in 1914, she offered her services as a voluntary worker to the ICRC, which had opened the International Prisoners of War Agency; the Agency was to make the name of the ICRC and Geneva known the world over. Marguerite van Berchem selffessly devoted her time and effort to the work at hand, and was soon appointed head of the German Service, a position she filled with skill and efficiency.

In 1939, when for the second time a generalized war made a battlefield of most of the world, Marguerite van Berchem returned to the ICRC. She had always been interested in Islamic culture, and saw the necessity of creating in the Agency a Colonial Service, separate from the French Service, to handle the cases of the many prisoners of war from the colonies. Because they spoke and wrote languages little-known beyond their borders, these POWs suffered in the European camps from the climate and the isolation, the lack of news and family parcels. For years, the Agency was the only link between them and their country. Marguerite van Berchem became the head of this Service, to which she brought her ability and her energy. After the war, the "colonial files" were of great usefulness to the French national POW bureaux whose documents had deen destroyed or were incomplete.

In the meantime, as the hostilities spread, the ICRC had to increase considerably the number of its collaborators. Marguerite van Berchem had the idea of calling persons of good will in other Swiss towns for help. Thus, under her direction, the auxiliary sections to the Agency were created; at their peak, these sections had over 1,000 staff, whose work was of inestimable value.

Marguerite van Berchem represented the ICRC on several important occasions, and in particular at the Fifteenth International Red Cross Conference in Tokyo in 1934.

In 1951, she was elected a member of the ICRC, and in 1969 an honorary member. Until a few years ago, and in spite of her age, she faithfully attended every Assembly, where her points of view, which 
reflected so much culture, experience and wisdom, were always well received. She also made generous donations to the staff pension fund, in aid of retired employees in need.

Those who knew her will not forget her engaging personality.

\section{Accession of the People's Republic of the Congo to the Protocols}

The People's Republic of the Congo deposited with the Swiss Government, on 10 November 1983, an instrument of accession to the Protocols Additional to the Geneva Conventions of 12 August 1949, relating to the protection of victims of international armed conflicts (Protocol I) and non-international armed conflicts (Protocol II), adopted in Geneva on 8 June 1977.

Pursuant to their provisions, the Protocols will enter into force for the People's Republic of the Congo on 10 May 1984, six months after the deposit of its instrument of accession.

The People's Republic of the Congo is the 34th State to become party to Protocol I and the 28 th to Protocol II.

\section{Accession of the Syrian Arab Republic to Protocol I}

On 14 November 1983, the Syrian Arab Republic deposited with the Swiss Government an instrument of accession to the Protocol additional to the Geneva Conventions of 12 August 1949 relating to the protection of victims of international armed conflicts (Protocol I).

In accordance with the articles of the Protocol, this accession will become effective on 14 May 1984, i.e. six months after the registration of the instrument of accession.

The Syrian Arab Republic is the 36th State to accede to Protocol I. The number of States parties to Protocol II remains 29. 